\title{
Contribution of Rupa Lake for Sustainable Food Security and Local Climate Change
}

\author{
Sajani Shrestha \\ Research Centre for Applied Science and Technology, Tribhuvan University, Kirtipur, Kathmandu 44600, Nepal
}

\begin{abstract}
Rupa Lake is small advancing eutrophic lake covering about 115 ha of the Lekhnath Municipality in Kaski district of western Nepal. The environment around the lake has been improved over a period of 10 years. Conservation practices were initiated by communities including the Rupa Lake Restoration and Fishery Cooperative (RLRFC). As a result, an abundance of non-timber Forest Products (NTFP) has increased considerably. At present, 49 NTFP are available in the lake basin. Some households (HH) i.e $10 \%$ has additional income from NTFP. It is an indirect source of food security for local people. They sell NTFP products to generate income. A few households have already started farming of NTFPs. Availability of fodder and fuel wood from community forest has significantly contributed to the livelihoods of people where as wild edible fruits and vegetables have become supplementary for food security. There is yearly food security for $57 \%$ of $\mathrm{HH}$ with $22 \%$ having surplus food. $5 \%$ of $\mathrm{HH}$ has food security for less than three months where as $19 \%$ HHs have food security for more than six months. However, livelihood and nutritional security have improved by fish farming in lake. This lake is most important for the local environment and also helps eco-tourism. The study found that $92 \%$ observed the climate change in the form of a rise in temperature ( $>70 \% \mathrm{HHs})$; unpredictable rainfall ( $>75 \% \mathrm{HHs}$ ); shifting rainfall $(>60 \% \mathrm{HHs}$ ); phonological changes $(>50 \%)$. It showed that the lake supports the restoration of natural water capacity, maintain local climate and sound environment by better natural resource management for an environment friendly ecosystem.
\end{abstract}

Key words: Community forest, livelihood, adoption, ecosystem, environment.

\section{Introduction}

Nepal is country facing food insecurity. Globally, Nepal ranks $145^{\text {th }}$ out of 187 counties Human Development Index 2014 [1]. Annual population growth rate of the country is 2.2 percent. It is estimated that the country's population in 2025 will reach 40.5 million; and will face difficulty in fulfillment of food requirements [2]. Looking at this scenario, Nepal will face serious food insecurity in future as well.

Nepal holds ten wetlands of global significance that adds $0.025 \%$ of wetlands cover to the global target of Ramsar (250 million ha). This proportion is a quite high figure in a small country like Nepal which only share $0.1 \%$ its landmass in the global comparison. Now, Lake Cluster of Pokhara Valley is also included in Ramar site in 2016. Nine lakes are Phewa, Beganas,

Corresponding author: Sajani Shrestha, Ph.D., associate professor, research fields: wetland and food security.
Rupa, Kamal Pokhari, Maidi, Khaste, Gunde, Neureni and Dipang. With this cluster includes $261.06 \mathrm{~km}^{2}$ [3]. Among them Rupa Lake is one of them.

\subsection{Wetland and Climate Change}

Wetlands are proven as unique and the most productive ecosystem with 7 percent coverage in the world. They provide provisional services as freshwater for drinking, irrigation, fishery, as well as cultural services. Wetlands also support services as ecosystem and hydrological balance and mitigate environmental disasters and calamities including climate change impacts. These days, wetlands are considered as foundation of sustainable development and prosperity of the local community by eco-tourism. Similarly, wetland is considered as fertile lands for agriculture and is also important for food security of the people. Wetlands are rich in biological diversity.

Every lake in valley has its own significance in biodiversity, ecosystem services and functions. Lakes 
and catchment areas provide home to many threatened and endemic plants, birds and wetland dependent mammals [4].

The wetlands provide habitat for several species of wildlife and lie within various ecosystems of high-mountain and lowland plains in Nepal. The Nepali term for wetland is "Simsar" which means land with perennial source of water. Swampy rice fields, water logged areas and ponds are also understood as wetlands in Nepal.

In Nepal, wetlands are important resources in term of biological, hydrological, social, economic, religious and cultural values. Wetlands conservation in Nepal has a time series story that started from 1950s. So many wetlands are either in government forests or in public lands. With this journey, Nepal has made active wetlands conservation after its commitment in the Ramsar Convention (1971) followed by the establishment of Koshi Tappu Wildlife Reserves in 1978, the first Ramsar site in Nepal. Nepal consists of over 6,000 rivers and rivulets, 3,252 glaciers, 2,323 glacial Lakes, 23,000 ponds, 163 wetlands including 48 Lakes of ox-bow-type in Terai, and several tectonic Lakes in high and mid-mountains [5]. Nine wetlands are already designated under the Ramsar sites in Nepal having seven of these within the PA system.

Climate change affects green sectors more than other sectors of the economy. Agriculture production depends on nature and gets affected by the change in the climatic parameters such as extreme weather events. Study reported that expected changes in frequency, duration intensity and geographic distribution of rainfall and snowfall and increased frequency, duration and intensity of droughts [6]. Effects of climate change on agriculture are particularly sensitive as the agriculture produces food and provides the primary source of livelihood. Climate change is expected to influence crop and livestock production, hydrological balances, input supplies and other components of agricultural systems reports that climate change will affect all four dimensions of food security, namely food availability, access to food, stability of food supplies, and food. Climate change has also created risks to the food security of the large number of population [7].

The 1996 World Food Summit defined food security as "existing when all people at all times have access to sufficient, safe, nutritious food to maintain a healthy and active life" Commonly, the concept of food security is defined as including both physical and economic access to food that meets people's dietary needs as well as their food preferences [8].

\subsection{Wetland and Food Security}

Food security is one of the big problems in South Asia. About three quarters of the poor, about 800 million people, live in Asia, primarily in Bangladesh, China, India and Nepal. The largest population of people affected by potentially critical shortage of land is also in the Southeast Asia because of living in poverty [9].

Nepal is a country highly vulnerable to food insecurity and its impact in health, nutrition, livelihoods, and overall national security. The Food and Agricultural Organization of the UN considers Nepal which represents a low-level of food security country. Over 50 percent of all households in Nepal have food in sufficiency for even half the year [10]. Food deficiencies are most pronounced in hill and mountain-areas with 13 of 16 mountain and 21 of 39 hill districts having a severe food deficit. Nineteen of 24 districts in the mid and far-western regions of Nepal are in food deficit condition. Vulnerability to food insecurity is also on the rise because of climate change. Climate change is making more and more difficulties particularly in low land or disaster prone areas.

Domestic food production is insufficient to meet per capita caloric needs; Nepal has become a net importer of food. Reliance on imports has made the poor increasingly vulnerable to price shocks and has exacerbated food insecurity. The majority of Nepal's 
populations are on small holder of farms for its livelihood. Many households operate on landholdings that are inadequate to produce enough annual food for survival. Certain families, particularly those from lower caste groups have landholdings in the adhiya system (share cropping on $50-50 \%$ basis to landowner and farmer); and are obliged to turn over a significant portion of their harvest to the wealthier or higher caste members holding the land. Nationally, 47 percent of the land owning HHs owned only 15 percent of the land with an average size of less than $0.5 \mathrm{ha}$, whereas the top 5 percent owned nearly 37 percent of land. Most Dalits (untouchable class) are landless.

Besides these weaknesses and challenges, Nepal has a rich natural resource with high biological value of wetlands that include high biodiversity of plant and animal genetic diversity. Similarly, fresh water originating from the Himalayas created a many wetlands with beautiful natural environment. These facts indicate that Nepal has a good prospect of diversifying and increasing agricultural production by wetland management and conservation for alleviating poverty and attaining sustainable livelihood. Most of the wetlands of Nepal are originated by Himalayas.

The direct uses of wetlands are fishing, food, medicine, agriculture, timber, Recreation \& tourism transport and water supply. Indirect uses of wetlands are nutrient $\&$ sediment, flood control information and storm and erosion protection. The optional of wetland are Potential Future use (both direct $\&$ indirect), and Future value information. Non-use of wetland existing value is rich in biodiversity, good habitat, religious-cultural heritage and center of research and education in terms of landscape \& aesthetic value. Wetland has spiritual value, unique ecosystem maintaining the integrity, source of genetic resources [11]. Despite these direct and indirect benefits wetlands are facing many problems. Some wetlands have site specific problems. Similarly, common problems are over extraction of resources such as food and NTFP products, drought, filled by sediments and sites, caused by flashfloods, natural calamities, felling the trees and vegetation in watershed areas, and encroachment of wetlands by people. Regardless to the number and sizes, the wetlands of Nepal are the persistent conventional sources to address livelihoods of many specially mountain communities including 10 percent of wetlands dependent ethnic communities like Jangar, Tharu, Jalahari, Majhi, Satar, Mushar, Brahmu and so on. Therefore, wetlands are important sources of food security to them.

Degradation of wetlands is due to expansion of agriculture and subsequent conversion of wetlands through drainage into rice fields, irrigation for enhancement of agricultural productivity; national, local and rural infrastructures. Similarly, overgrazing of livestock, over-fishing and associated disturbances, siltation due to degradation of the watershed areas, which are often trans-boundary in nature are the causes of depredation of wetlands. Also pollution of water due to industrial, urban agrochemicals and other types of pollutants including from trans-boundary sources leads to depreciation of water quality of wetlands [12].

As in the world, Nepal's wetlands are also degrading and which impact on regulating local micro-climate. It also helps maintaining the population of flora and fauna of biodiversity conservation. Further, it creates favorable environment for recreation, tourism promotion and environmental businesses through lake management. Wetlands in the Pokhara valley which are unprotected are even more at risk: from drainage, diversion, obstruction, siltation, encroachment, infrastructure development, land use changes, pollution and poison to kill fish resulting in a marked reduction in bird numbers and species diversity since the 1970s [13]. Among them, Rupa Lake has same problem.

Lake serves an important role in the hydrological cycle of the region. Rupa lake is the third biggest Lake of Pokhara valley. Similarly, it also plays a significant role in groundwater recharge, flood control and 
sediment trapping. It is also important for evapotranspiration. Habitat of Rupa Lake and its catchment consists of open water, marsh and swamp areas, paddy fields and forests. It supports a number of floral and faunal species. This article is based on research of "Role of Wetland in Food Security and Livelihood of Local People in Rupa Lake Area in the Context of Climate Change". It also addressed the issues related to food security and environmental impact linked with contemporary issue of climate change in Rupa Lake Area of Kaski district.

\section{Methodology}

Rupa Lake is a small advancing eutrophic Lake that falls in 4 VDCs and wards 10 \& 11 of Lekhnath Municipality in Kaski district of Nepal (28 $08^{\prime} 39.72^{\prime \prime}$ $\mathrm{N}$ and $\left.84^{\circ} 06^{\prime} 29.29^{\prime \prime} \mathrm{E}\right)$. It covers an area of 115 ha with marshes and paddy field along its shores in its basin of $30 \mathrm{~km}^{2}$. This study was carried out in 2012-13 in Kaski district at Rupa Lake area. Research was conducted by collecting both primary and secondary data.

The primary data were collected by field observation, group meeting, focus group meeting, semi-structured interview, stakeholder consultation and laboratory analysis of water quality. Meteorology data are referred from the Department of Hydrology and Metrology, Nepal. Secondary data were collected by review of existing data and information relevant to the area or topic (published and unpublished), like reports, census data, research findings, municipal and VDC statistics.

Household Food Insecurity Access Scale (HFIAS) tool was used for the measurement of food insecurity as suggested by Coates, J., Swindale, A., and Bilinsky, P. (2006) [14]. A set of nine questions was used as a research tool and the data analysis was done as per that tool. The HFIAS indicator categorizes households into four levels of household food insecurity (access) food secure, mild, moderately and severely food insecure.
The monthly meteorology data for the last 30 years were taken from Pokhara Airport station, which is the closest meteorological station to Rupa Lake. The meteorological data included minimum, maximum and average temperature, and rainfall. These data were computed to reveal the impact of climate change in terms of temperature region and rainfall in the study area. The result was also used to verify local people's experience/perception in this regard. Data analysis was done in SPSS and Microsoft Excel.

\section{Results and Discussion}

\subsection{Climate Change: Meteorological Data and People's Experiences}

Major two parameters were taken as temperature (maximum, minimum and average) and rainfall. Metrology data showed that the trend of temperature of average, maximum and minimum is increasing about 2 degree in 30 years. Maximum and minimum temperatures are also in increasing trend. However, rainfall pattern is oscillation. The research found that climate change in the form of rise in temperature $(>$ $70 \% \mathrm{HHs}$ ); unpredictable rainfall ( $>75 \% \mathrm{HHs}$ ); shifting rainfall $(>60 \% \mathrm{HHs}$ ); phonological changes $(>50 \%)$. Of the total sampled households, 92 percent shared their experiences regarding the impacts of climate on climatic parameters, wetland ecosystem, agriculture, food security and livelihoods. Rise in temperature, unpredictable rainfall, shift in rainfall pattern and phonological changes in plants were the indicators of climate change. It is evidenced that the metrological data and people's perception from questionnaire survey are similar in the context of climate change.

\subsection{Climate Change: Agriculture and Livelihoods}

Nepal is hit hard by climate change. Atmospheric temperature in Nepal is rising at a rate higher than the global average, with a $1.8^{\circ} \mathrm{C}$ increase between 1975 and 2006, while precipitation has become increasingly unpredictable. It is similar in this research area too. 
Furthermore, threats to biodiversity, deforestation, and increased frequency of extreme weather events have affected agricultural production and undermined the livelihoods of the rural poor [15]. Rain-fed farming system is major problem on the uplands above Rupa Lake wetland area. Some farmers in the study area responded that the climate change is visible as an impacts on agriculture, forestry and wetland, and therefore in their lifestyles and livelihoods. They remarked that the climate has changed their lifestyle and local farmers have adapted different coping strategies.

Nepalese fish farming practice has subsistence nature. Now, Rupa lake fish farming is based on professional and livelihood purpose to fulfill the demand of protein. Furthermore, intensive development and improvement is necessary to meet the demand of fisheries products, which is a source of low-priced but healthy animal protein supporting for food/nutritional security for the people and marginalized communities. Marginalized and lower middle class people cannot readily afford for meat; therefore wetland is the good source of protein supplement for them, particularly those residing in the wetland ecosystem. Keeping this reality into consideration, Rupa Lake Restoration and Fishery Cooperative is doing fish farming in Rupa Lake.

\subsection{Climate Change: Food Security and Local Community}

Majority of the households in the study area depended in agriculture for their livelihoods. The following impacts of climate change were realized in the context of food security system during the last 30 years in the study area (Table 1). Above 65 percent of the respondents stated that as an impact of climate change there has been decline in crop production. It means impact of climate change is negative in the study areas and creates the serious consequences on the level of food production and food security in the local level. Therefore climate change is crucial for livelihoods of local communities.

It means it has negative impact on food production that has direct relationship with food security. If climate change negatively affects the crop production, it creates serious consequences on the level of food/nutritional security. About $50 \%$ have food security for 9-12 months in the study areas. The Figure 1 shows the status of food security of the study area.

Livestock is one of the major components of Nepalese agriculture and food security. It includes poultry, cattle, buffalo, goat and pig farming. In the study area, majority of the households had similar kinds of the livestock. Ninety percent livestock contributed in the household food security as fertilizer in agriculture field and as cash during food shortage time. They are used to sale the livestock during food shortage. Most of the households had buffalo, goats and poultry as major livestock. People rely upon the nearby watershed and wetland area to meet the demand of food security. They were also relying upon various wetland products and forest resources to escape from the food insecurity. Moreover, people were willing to do bee keeping, coffee production and fish farming, poultry raising and cultivate ayurvedic (herbal) medicine as alternative source of income.

\subsection{Adaptation Strategies of Climate Change for Food Security}

Subsistence farmers have adopted different strategies to cope with climate change because of the

Table 1 Impacts of climate change in food security system during the last 30 years.

\begin{tabular}{llll}
\hline SN & Impact of climate change & Percent (\%) & Remarks \\
\hline 1 & Decline in food production & 54 & \\
2 & Threats in livestock husbandry & 15.7 & \\
3 & Increased vulnerability & 4.3 & People could not respond properly \\
4 & Have no idea & 26 & \\
\hline
\end{tabular}




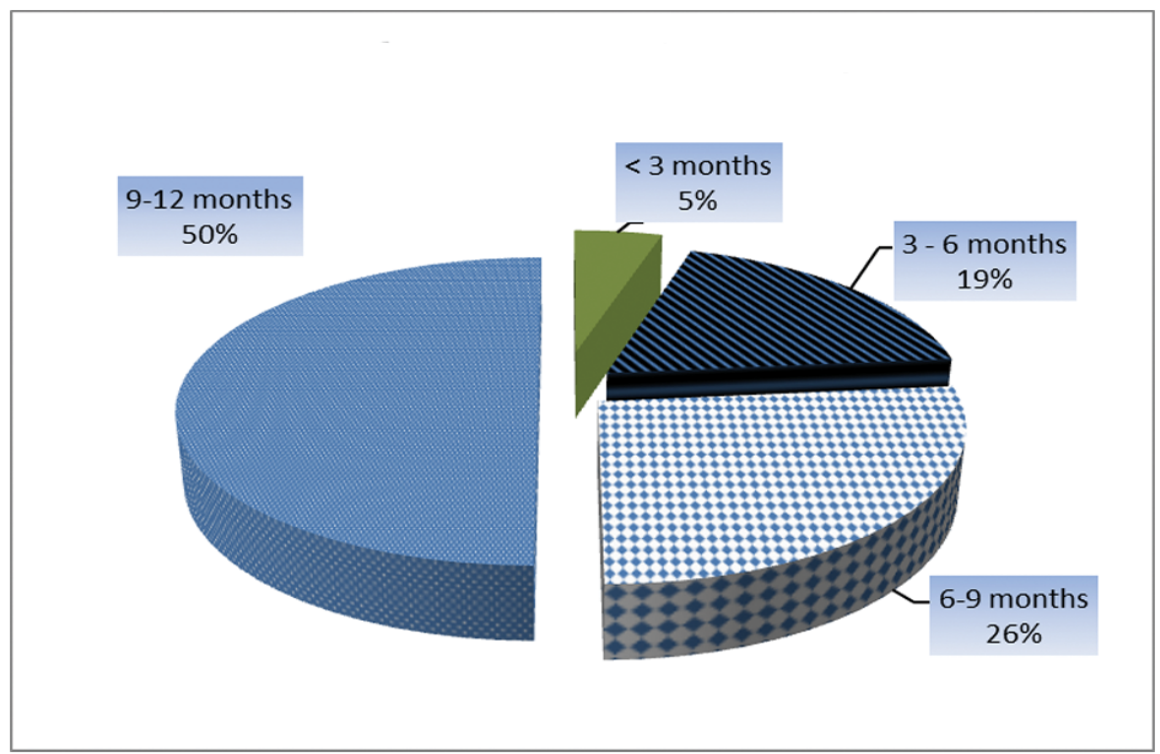

Fig. 1 Food security status in study area.

less food production in the study area. About 74 percent of households are aware about the effect of climate change and had adopted different strategies to resist against the effect of climate change. Out of the 74 percent of HHs, more than 50 percent of the household use chemical fertilizers and agriculture inputs to cope against the climate change and to increase the production yields. Only these coping strategies are not effective to resist against the climate change effect. All other strategies adopted against the climate change are very few and insignificant to resist the effect of climate change. Many households are unknown and do not adopt any types of strategies too. All these problems directly affect the production of these major crops. Mostly, subsistence farmers have adopted different strategies to cope with climate change because of the decline in food production. Most common strategies are use of chemical fertilizer/pesticide, hybrid seeds use of bio-gas and change in agriculture farming system. About 77, 52 and 50 percent have adopted chemical fertilizer/ pesticides, bio-gas and increased agriculture input such as compost \& bio manure respectively as coping strategies for climate change. Most of them told that they were adopting mixed cropping; and were using short duration crops. Almost all of the respondents reported that they were using organic manure/compost and bio-pesticides whenever need arises.

Most of the farmers rely upon the rainfall for their agricultural production. Unpredictable rainfall and shifting pattern of rainfall affect the production of food. Besides agriculture, people are involved in different alternative source of income generation for livelihood. Vulnerable households for the food security often responded by skipping meals, reducing food intake, selling assets like livestock, temporary migration for employment, cross boarder migration and day labor.

Remittance has become the highest priority for alternative source of income in the respondents' household. 61.4 percent of the households informed that at least one household members are in abroad to earn money to secure food and livelihood. Using non-timber forest products for ayurvedic (herbal) medicine production is also alternative source of income for livelihood. Storage of food is also help in food security. All cereals storage technique is tradition. It means $10 \%-30 \%$ losses by rodents and pest. However, more than $80 \%$ practices vegetable drying when they have adequate vegetables. About $60 \%$ make pickles, Mashura (value added vegetable drying) and fermentation. They use these food items during 
the vegetable scarcity time.

\subsection{Food Security Assessment}

The HFIAS indicator categorizes households into four levels of household food insecurity (access) food secure, and mild, moderately and severely food insecure as per methodology description. The categorization scheme is designed to ensure that a household's set of responses will place than in single, unique category. Table 2 shows that about five percent have severely food insecure in the study areas.

\subsection{Climate Change and Wetland}

Wetland also plays an important role for the regulation of climate change and the people residing nearby the wetland areas. However, long term climate change may affect the wetland areas and the resources, those who are dependent on different purposes.

Presently, Rupa Lake area is also in decreasing trend. Main cause of lake shirking is siltation problem. Previously, Rapa Lake is 135 hectares now it is 90 hectares based the area measurement. 10 years back the depth of the Lake was 10 meter and now it is only 4-6 meters [16]. But its height (volume of water) of the lake is extremely reduced. So the lake has big problem of siltation as per Lake Conservation
Committee. Major cause of siltation is deforestation in upstream, development works, soil erosion and cultivation practices in upstream and erosion prone areas. It affects to downstream. These practices make the Nepalese wetlands in verge of extinction. Similar situation is found in Rupa Lake. If the conservation activities are not done by Rupa Lake Restoration and Fishery Cooperative, the Lake is going to extinct.

Climate change is slow in process of resources changes. It cannot be seen by direct observation but if we do in-dept study, it can be observed. Different resources such as drinking water, irrigation and domestic water supply, fish supply, timber, fiber, fuel wood and fodder supply are provided by lake in the study areas. It also provides some wild foods, medicinal plants and handicraft raw materials and so on. However, the impact of climate change affects all these resources of wetland. The study shows that only fish supply is increasing and remaining others resources are in declining rate such as aquatic flora and fauna by Wetland Inventory, Assessment and monitoring Tools [17]. Therefore, it is necessary to perform proper conservation plan and that can save them from being history. Table 3 shows climate change impact in resources changes during the last 30 years.

Table 2 Assessment of food security by HFIAS score method.

\begin{tabular}{llll}
\hline SN & Status of food security & $\%$ & Remarks \\
\hline 1 & Food secured & 57 & From different sources of income \\
2 & Mild food insecure & 32 & \\
3 & Moderately food insecure & 6 & \\
4 & Severely food insecure & 5 & \\
\hline
\end{tabular}

Table 3 Impact of climate change on wetland resources.

\begin{tabular}{lllll}
\hline SN & Impact observed of climate change & Increased & Decreased & Indifferent \\
\hline 1 & Core water area & - & 98.5 & 1.5 \\
2 & Water quality in general & 19.0 & 52.4 & 28.6 \\
3 & Water volume & - & 98.5 & 1.5 \\
4 & Birds bio-diversity & 8.3 & 83.3 & 8.3 \\
5 & Fish biodiversity & 19.3 & 78.9 & 1.8 \\
6 & Herpetofauna & 6 & 58.0 & 36.0 \\
7 & Phytoplankton density & 4.1 & 59.2 & 36.7 \\
8 & Zooplankton density & 4.2 & 60.4 & 35.4 \\
9 & Siltation & 100 & & \\
\hline
\end{tabular}




\subsection{Forest and Climate Change}

Forest ecosystems play an important role in the global bio-geochemical cycles. Forests act both as sources and sinks of green house gases (GHGs), through which they exert significant influence on the earth's atmosphere climate. Forests can contribute to the mitigation of climate change.

Forest area is an important aspect to regulate the local climatic pattern too. In the study area, the present status of the forest as per the respondent's remarks is in average condition. Above $76.6 \%$ of the respondents tell the average condition of the forest. The study shows that the condition of the forest was bad before 30 years [18]. There was not any conservation effort in community forest at that time.

The surrounding forest in and around the wetland and watershed area of the lake are used for the various purposes by local people. Fuel wood and fodder are the mostly used products of the forest by the local people. Most of the fuel wood demand was met by the nearby community forest and few of them only use their private land to fulfill the need of the fuel wood. Above 98 percent fuel wood and 85 percent fodder are fulfilled by community forest.

At present, $81 \%$ of the respondents tell that they are not having any fuel wood problem. This also indicates the forest condition in the present situation is somehow good. People rely upon the forest for not only to meet the fuel wood demand but also they have access to various forest products like fodder, timber, NTFPs and grazing access too. Presently, 49 NTFP are available in the lake basin areas [16]. Some households earn additional income about 10 percent from NTFP. It is indirect source of food security by selling NTFP products. A few households already started farming of NTFPs. Availability of fodder and fuel wood from community forest has been significantly contributing to livelihoods where as wild edible fruits and vegetables have supplementary for food security [16].
Afforestation is considered as conservation of forest and it mitigates the climate effect of local climate. Therefore, Rupa cooperative is supporting and doing conservation activities such as awareness of conservation forest, NTFP collection and cultivation, afforestation programme, school awareness programme for conservation and plantation of trees in community forest to mitigate the climate change in and around the surrounding areas of Lake Basin. It helps to protect the beauty of lake and control the siltation to the lake. Still, people are dependent on the community forest for fuel wood, fodder, timber and medicinal plant. They are also conserving of community forest by plantation of new trees and managing the community forest by community.

\subsection{Climate Change and Gender}

Climate change directly affects to women. Rising temperatures and unpredictable precipitation patterns are directly related subsistence farming for their livelihoods. In a patriarchal society, women are mostly responsibility for domestic activities such as housekeeping, childrearing, cooking, and fetching water and firewood collection. In this community, the situation is changing as many men and boys are migrating in search of on-farm work and abroad employment. $61 \%$ of males are working abroad. In this situation, all women whose male are abroad have extra responsibility in all agricultural and household works, taking care of family and livestock and managing for the food security [19]. This situation makes women more overloaded in the research areas.

\section{Conclusion}

Food security in the research area is under threat due to impacts of climate change. The linkages of climate change with food production, rising prices, population migration, gender roles, and malnutrition are intricate. Therefore, the issues of food security and livelihoods need to be addressed urgently keeping in view the changing local context, micro climate and 
people's capabilities within the broader framework of the entitlements and rights of the local small farmers, women and marginalized groups. Despite these things, Nepal is rich in biodiversity including ecological and ethno-cultural diversity. Nepal has a good prospect in diversifying and increasing agricultural production through integrated sustainable management of wetland for ensuring food/nutritional security. A similar situation is found in the Rupa Lake area.

Food insecurity and climate change are the major challenges of the twenty first century, which directly and indirectly affect the wetland communities. Due to the climate change people are adopting different strategies for their food security and livelihoods. Major adoptions include using early maturing hybrid and improved crop varieties with heat or drought tolerance, integrated pest management, and integrated plant nutrient management.

Climate change is a real challenge for agriculture, forestry and wetland management, and obviously for livelihoods and food security. Its effects cannot be completely controlled but effective micro-level planning is necessary for forestry and wetland management. However, strategies can be developed based on local people's traditional knowledge and practices to reduce the effects of climate change or cope with the changes in various climatic parameters. The governmental and non-governmental actors should come closer to coordinate their meaningful efforts in this direction. Some mitigation oriented or conservation practices such as community forest, private forest conservation, sustainable and eco-friendly crop cultivation, environment friendly development activities and conservation related education are more appropriate. That will positively affect micro climate of small wetlands like Rupa Lake. Similar replication can have positive effect on other micro climates of the country. The community's role in the wetland and lake conservation activities is quite appreciable in the Rupa Lake area. This fact provides ground to suggest that the government at various levels should come up with appropriate skill development, awareness raising activities and marketing assistance plans for the self-reliance oriented capacity building of the local people depending on Rupa Lake for their livelihoods.

\section{Acknowledgement}

This paper is a part of research project supported by University Grant Commission (UGC). I sincerely acknowledge to UGC for providing financial support to conduct this research and thank those who have supported the research project.

\section{References}

[1] Human Development Report. 2014

[2] FAO. 2010. Assessment of Food Security and Nutrition Situation in Nepal. An Input for the Preparation of NMTPF for FAO in Nepal.

[3] RAMSAR 2016. Ramsar Information Sheet for LCPV. 2016. https://rsis.ramsar.org/ris/2257.

[4] Kafle, et al. 2008. "Status of and Threats to Water birds of Rupa Lake, Pokhara, Nepal." Journal of Wetlands Ecology 2: 9-12.

[5] HLl. 2012. Report of Inventory of Himalayan Lakes (HLI) of Nepal.

[6] FAO and SAARC. 2008. Regional Strategies and Programme for Food Security in the SAARC Member States. FAO, August.

[7] Burke, M. M., and Moench, Y. 2003. Rethinking the Approach to Ground Water and Food Security. Food and Agricultural Organization.

[8] FAO. 1996. "World Food Summit Plan of Action." http://WWW.FAO.ORG/WFS/INDEXEN.HTM.

[9] Swaminathan, M. S. 1996. Sustainable Agriculture towards Food Security. Konark Publ., ND.

[10] FAO, WFP and IFAD. 2012. The State of Food Insecurity in the World. Rome: FAO.

[11] Barbier, E. B., Acreman, M., and Knowler, D. 1997. Economic Valuation of Wetlands: A Guide to Policy Makers and Planners. Ramsar Convention Bureau.

[12] Benthem, W., and Lavieren, L. P. V. 1994. Wetlands Are not Wastelands: A Manual and Strategy for Conservation and Development of Wetlands-Srilanka, Wetland Conservation Project, Central Environmental Authority.

[13] Karki, A. B., Shrestha, A., and Rana, E. B. 1997. "Conservation Perspective of Dipang Tal." Pokhara. Danphe 6 (2): 2. 
[14] Coates, J., Swindale, A., and Bilinsky, P. 2006. Household Food Insecurity Access Scale (HFIAS) for Measurement of Food Access: Indicator Guide, USAID.

[15] Rajbhandari, B. P. 2011. "Bio-intensive Farming System: Validation of Its Approaches in Increasing Food Production, Improving Food Security and Livelihoods." Nepalese Journal of Agricultural Sciences 9: 112-22.

[16] Rupa Lake Co-operative Report 2012.

[17] Ministry of Forest and Soil Conservation, 2011. Wetland Inventory, Assessment and Monitoring Tool
(WIAMT), Conservation and Sustainable Use of Wetlands in Nepal. MoFSC, GoN.

[18] Shrestha, S. 2015. "Community Response to Climate Change for the Food Security in Rupa Lake Basin Area, Kaski District of the Western Nepal." University Grant Commission, The Journal of University Grant Commission 4 (1) 179-93.

[19] Rajbhandari, B., and Shrestha, S. 2013. "Role of Wetland in Food Security and Livelihood of Local People in Rupa Lake in the Context of Climate." The Journal of Agriculture and Environment 13: 170-175. 